\title{
Analysis of Student Responses to Module Development Based on Islamic Integration in Biology Learning in Class XI
}

\author{
Miftahul Khairani ${ }^{(1)}$, Irda Wahidah Nasution ${ }^{(2)}$
}

STKIP Asy-Syafi'iyah International Medan

Miftahulkhairani92@gmail.com (1), irdawahidah26@gmail.com (2)

\begin{abstract}
ABSTRAK
Penelitian ini bertujuan untuk mengetahui respon siswa terhadap penggunaan modul berbasis integrasi Islam dalam meningkatkan hasil belajar siswa pada mata pelajaran sistem pencernaan pada siswa kelas XI Pondok Pesantren Darul Qur'an. Metode penelitian yang digunakan dalam penelitian ini adalah penelitian deskriptif. Jenis penelitian deskriptif yang digunakan dalam penelitian ini adalah survey dengan menggunakan kuesioner. Instrumen penelitian yang digunakan adalah angket respon siswa. Analisis angket respon siswa menunjukkan bahwa $83 \%$ siswa menyatakan bahwa penggunaan modul pembelajaran dapat meningkatkan hasil belajar siswa.
\end{abstract}

Kata Kunci : Respon Siswa, Pengembangan Modul, Modul Pembelajaran Terintegrasi, Pembelajaran Biologi

\begin{abstract}
This study aims to determine student responses to the use of Islamic integration-based modules in improving student learning outcomes on the subject of the digestive system in class XI Darul Qur'an Islamic Boarding School. The research method used in this research is descriptive research. The descriptive research used in this research is a survey using a questionnaire. The research instrument used was a student response questionnaire. Analysis of the student response questionnaire showed that $83 \%$ of students stated that using the learning module could improve student learning outcomes.
\end{abstract}

Keywords : Student Response, Module Development, integrated learning module, Biology Learning

\section{INTRODUCTION}

Education aims to change human life for the better. This change can be realized with the help of teachers as educators. In order for changes to occur in accordance with the times, a teacher must always pay attention to the development of Science and Technology (Science and Technology). Paying attention to the development of science and technology can help teachers improve skills in managing the learning process in the classroom. Learning is a complex phenomenon that is influenced by several factors, one of which is teaching. A person will learn from what he is taught (Huda, 2014). One of the students' success in learning is determined by the competence of the teacher in the accuracy of using the method in learning. Students have different levels of ability to understand the material, so that teaching materials are needed that can make students learn independently. Padmapriya (2015) states one way of achieving independent learning is by using modules. Modules are teaching materials arranged systematically and attractively including material content, methods and evaluation that can be used independently to achieve learning objectives according to the level of complexity. Sari (2017) in his research revealed that the use of teaching materials in the learning process will produce a good response for students. The learning module is subject matter that is arranged in writing so that students can understand the material independently to minimize help from others. Modules have advantages over other teaching materials. The advantages of the module can be seen from the completeness of its contents. The module contains a complete learning step. According to Madya, the 
Khairani M, Wahidah Nasution I : Analysis of Student Responses to Module Development Based on Islamic Integration in Biology Learning in Class XI

module is equipped with practice questions, answer keys and assessment instructions. These practice questions can be used to measure students' level of mastery of the material. The advantages of modules compared to textbooks are two-way communication, clear structure, simple language, and motivation (Syahroni, et al., 2016). The use of modules in learning can help students gain an understanding of concepts or learning materials (Ardianti, SD, \& Ristiyani, 2017). Based on the description of the problem above, the researcher formulates the problem in the study is to find out how students respond to the use of learning modules. The purpose of this research is to find out how students respond to the use of learning modules. The benefits of research carried out as teaching materials that can provide additional knowledge for students in religious and biological knowledge.

\section{METHOD}

In this development research used two data analysis techniques, namely qualitative descriptive analysis techniques and quantitative descriptive analysis. This descriptive analysis technique is used to revise the learning media that is being developed. Data obtained from the results of reviews of content experts in the field of study or subject, instructional design experts, instructional media experts, teachers and student trial results. This data analysis technique was carried out by grouping information from qualitative data in the form of input, response, criticism, and suggestions for improvement contained in the questionnaire and interview results. Quantitative descriptive analysis is a method of data processing that is carried out by systematically compiling in the form of numbers and / or presentations regarding an object under study, in order to obtain general conclusions. In this study, quantitative descriptive analysis was used to process the data obtained through a questionnaire in the form of scores. The sample in this study were 37 students of class XI MIA 1 Darul Qur'an Islamic Boarding School. The instrument used was in the form of a questionnaire that had been validated by teaching material experts, material experts, linguists, religious experts, and teacher responses with validation results that stated that the instrument was suitable for use. The form of the questionnaire used was a closed questionnaire. Questionnaire containing 30 question items that have a score of 1-4 with 2 choices of answers to positive and negative statements. Development research is a process for developing and validating products in the form of materials, media, tools and or learning strategies that will be used in education. In this study, the product developed was a Learning Module in Biology, namely the digestive system of food in humans.

The questionnaire analysis was obtained based on the following steps:

1. Each answer given by the student, a score was calculated. In this study, for a positive statement a score of 4 was obtained if the student answered very feasible, a score of 1 if the student answered very improperly, conversely if a negative statement a score of 1 was obtained if the student answered very feasible, conversely a score of 4 if the student answered very improperly.

2. Recapitulate the scores obtained by each student.

3. Calculate the presentation of scores calculated using the formula

Percentage $=\frac{\text { the number of student who answerd }}{\text { total number of student }} \times 100 \%$

4. Determine the criteria for interpretation score each item statement with the criteria. 
Khairani M, Wahidah Nasution I : Analysis of Student Responses to Module Development Based on Islamic Integration in Biology Learning in Class XI

Table 1. Interpretation of score

\begin{tabular}{|l|l|}
\hline Percentage & Category \\
\hline $0-20 \%$ & Very feasible \\
\hline $21-40 \%$ & Eligible \\
\hline $41-60 \%$ & Not feasible \\
\hline $61-80 \%$ & Very improper \\
\hline
\end{tabular}

5. Interpret the average score response student based on the score interpretation criteria

Table 2. Criteria for student responses

\begin{tabular}{|l|l|}
\hline Percentage of & Categories \\
\hline $83 \% \leq \mathrm{RS}$ & Very feasible \\
\hline $70 \% \leq \mathrm{RS}<83 \%$ & Feasible \\
\hline $50 \% \leq \mathrm{RS}<70 \%$ & Not feasible \\
\hline Hospital $<50 \%$ & Very unfit \\
\hline
\end{tabular}

\section{RESULT AND DISCUSSION}

Based on the results of the calculation of the material expert test, the achievement level was $89 \%$ so that it was in good qualification. Based on the results of the calculation of the instructional media expert test, the achievement level is $90 \%$ so that it is in very good qualifications. Based on the results of the calculation of the linguist test, the achievement level is $90 \%$ so that it is in very good qualification. Based on the results of the calculation of the religious expert's test, the achievement level was $88 \%$ so that it was in good qualification. Based on the results of the calculation of the test to the teacher, the achievement level is $90 \%$ so that it is in very good qualification. As a revised development product based on the assessment of material experts, instructional media experts, linguists, religious experts and teachers, then group trials were carried out on the developed media. As the subject of this group trial were 30 students of the Darul Qur'an Islamic Boarding School MA Pondok Pesantren. The average percentage of $83 \%$ is in good qualification.

Table 3. Conversion level of attainment

\begin{tabular}{|l|l|}
\hline Achievement Rate (\%) & Qualification \\
\hline $90-100$ & Very Good \\
\hline $80-89$ & Good \\
\hline $65-79$ & Enough \\
\hline $55-64$ & Poor \\
\hline $0-54$ & Very Poor \\
\hline
\end{tabular}


Khairani M, Wahidah Nasution I : Analysis of Student Responses to Module Development Based on Islamic Integration in Biology Learning in Class XI

Response is a person's tendency to take certain attitudes, both positive and negative. In this study, students' responses will be seen after using the learning module which is measured using a questionnaire filled out by students. Response is a response or feelings of students after participating in learning. Response means reaction or response, namely acceptance or rejection, as well as indifference to what the communicator says in the message. Student responses are traced through a questionnaire that is filled in after students take problembased learning. Student response measured in this study consisted of 2 criteria, namely student responses to the suitability (relevance) of student learning activities and reactions after participating in learning. The results of student response questionnaires can be seen in Table 3 below:

Table 4. Student Response Results for positive and negative

\begin{tabular}{|c|c|c|c|}
\hline \multirow[t]{2}{*}{ No } & \multirow[t]{2}{*}{ Statement } & \multicolumn{2}{|c|}{ Percentage of Answers } \\
\hline & & Positive & Negative \\
\hline 1 & $\begin{array}{l}\text { I receive information about the } \\
\text { material easily }\end{array}$ & $100 \%$ & $0 \%$ \\
\hline 2 & $\begin{array}{l}\text { I can conclude a problem } \\
\text { well }\end{array}$ & $86 \%$ & $14 \%$ \\
\hline 3 & $\begin{array}{l}\text { I became more courageous in } \\
\text { asking about the material }\end{array}$ & $83 \%$ & $17 \%$ \\
\hline 4 & $\begin{array}{l}\text { I became more active in the } \\
\text { learning process }\end{array}$ & $76 \%$ & $24 \%$ \\
\hline 5 & $\begin{array}{l}\text { By using learning modules } \\
\text { I can explain about the } \\
\text { human digestive system }\end{array}$ & $86 \%$ & $14 \%$ \\
\hline 6 & $\begin{array}{l}\text { With orientation activities I } \\
\text { find out the purpose of } \\
\text { learning the human digestive } \\
\text { system material }\end{array}$ & $71 \%$ & $29 \%$ \\
\hline 7 & $\begin{array}{l}\text { With a problem I } \\
\text { can solve it by thinking } \\
\text { critically }\end{array}$ & $78 \%$ & $22 \%$ \\
\hline 8 & $\begin{array}{l}\text { By looking for information, } \\
\text { my learning outcomes have } \\
\text { increased }\end{array}$ & $84 \%$ & $16 \%$ \\
\hline \multicolumn{2}{|c|}{ Average } & $83 \%$ & $17 \%$ \\
\hline
\end{tabular}

\section{Discussion}

Based on table 3 shows that the response of students on average $83 \%$ responded that in the positive category. This means that students respond that using Islamic integration-based learning modules can improve their learning outcomes. In the first question item, the percentage score was obtained at $100 \%$. This shows that the learning module used is able 
Khairani M, Wahidah Nasution I : Analysis of Student Responses to Module Development Based on Islamic Integration in Biology Learning in Class XI

to help students receive material easily. The learning module that is applied is a learning module that integrates Islam. According to Anam (2016) inquiry-based learning has advantages, namely (1) students play an active role in finding important concepts; (2) Open ended topic, where students can learn through various sources, such as experiences and everyday environments with unlimited themes; (3) Intuitive, imaginative, and innovative, meaning that students can learn by maximizing their full potential, from creative to imagination; (4) opportunities to find discoveries, for example by observation and experiment. Through these four things students will get the results of the material they are learning. Meanwhile, Wena 2009 suggests that the learning module includes a series of activities aimed at making it easier for students to achieve a set of learning objectives. The second question item, the percentage score was $86 \%$, with a very positive response category. This shows that the use of Islamic integrated learning modules can make it easier for students to solve problems. Teaching by using modules provides opportunities for students to explore in solving problems according to the background knowledge and habits of each individual. The third item question got a percentage of $83 \%$ with a positive category. This shows that using this learning module can make students more active in asking questions. While the fourth item question obtained a percentage of $76 \%$ with a positive category. This proves that student learning outcomes have increased. The fifth item question got a percentage of $86 \%$ with a very positive category. The sixth to eighth item questions obtained by an average student response in the positive category. This proves that using Islamic integrated learning modules can improve student learning outcomes. A person is said to have increased learning outcomes if he is able to demonstrate the ability to identify significant problems, analyze arguments, evaluate by comparing the truth of interpretations, find the elements needed to make conclusions, provide convincing explanations, and make decisions from the results obtained (Filsaime, 2008).

\section{CONCLUSION}

Based on the results of the discussion and analysis that has been carried out, it can be concluded that the development of a learning module in Biology class XI at MA Darul Qur'an Islamic Boarding School is declared to be feasible with the results of research or trials as follows. (1) Linguist with an achievement level of $90 \%$ in very good category. (2) Experts in learning media with an achievement level of $90 \%$ in the very good category. (3) Material expert with an achievement level of $89 \%$ in the good category. (4) Religious experts with an achievement level of $88 \%$ in the good category. (5) Teachers with an achievement level of $90 \%$ in the very good category. (6) Group trials with the achievement level obtained were $83 \%$ in the good category.

\section{DAFTAR PUSTAKA}

Anam. (2016). Pembelajaran Berbasis Inkuiri Metode dan Aplikasi. Yogyakarta: Pustaka Pelajar.

Ardianti, S.D, \& Ristiyani, R. (2017). Pemahaman Pendidikan Seks Usia Dini Melalui Modul Anggota Tubuh Manusia. Jurnal Pendidikan Sains, 5 (2), 65-70.

Asfiah, N., Mosik, \& Purwantoyo, E. (2013). Pengembangan Modul IPA Terpadu Konstektual Pada Tema Bunyi. Unnes Science Education Journal, 2(1), 188- 195.

Filsaime, D. K. (2008). Menguak Rahasia Berpikir Kritis Dan Kreatif. Jakarta: Prestasi pustakaraya.

Hidayati, N. dan M. H. N. (2013). Respon Guru dan Siswa Terhadap Pembelajaran Permainan Bolavoli yang Dilakukan dengan Pendekatan Modifikasi (pada Siswa Kelas V SDN Wateswinagun I Sambeng- Lamongan). Jurnal Pendidikan Olahraga Dan Kesehatan, 1(1), 104-106. 
Khairani M, Wahidah Nasution I : Analysis of Student Responses to Module Development Based on Islamic Integration in Biology Learning in Class XI

Huda, M. (2014). Model-model Pengajaran dan Pembelajaran: Isu-isu Metodis dan Paradigmatis. Yogyakarta: Pustaka Pelajar.

Mahanal, S. (2007). Penerapan Pembelajaran Berdasarkan Masalah dengan Strategi Kooperatif Model STAD pada Mata Pelajaran Sains untuk Meningkatkan Kemampuan Berpikir Kritis. Jurnal Penelitian Kependidikan.

Muh Tawil, L. (2013). Berpikir Kompleks dan Implementasinya dalam Pembelajaran IPA. Makasar: Badan Penerbit Universitas Negeri Makassar.

Padmapriya, P. V. (2015). Effectiveness of Self Learning Modules on Achievement in Biology Among Secondary School Students. International Journal of Education and Psychological Research, 4(2), 44-46.

Riduwan. (2013). Belajar Mudah Penelitian untuk Guru-Karyawan dan Peneliti Pemula. Bandung: Alfabeta.

Saglam, H. I. (2011). An Investigation on Teaching Material used in Social Studies Lesson. The Turkish Online Journal of Educational Technology, 1(10).

Sari, D. puspita. (2017). Respon siswa terhadap modul system eksresi manusia pada pembelajaran biologi kelas XI SMA. universitas tanjungpura.

Sujiono \& Widiyatmoko, A. (2014). Pengembangan Modul IPA Terpadu Berbasis Problem Based Learning Tema Gerak untuk Meningkatkan Kemampuan Berpikir Kritis Siswa. Unnes Science Education Journal, 3(3), 685-693.

Syahroni, M.W., Dewi, N. R., K. (2016). The Effect of Using DIGIMON (Science Digital Module) With Scientific Approach at the Visualization of Students' Independence and Learning Results. Jurnal Pendidikan IPA Indonesia, 5(1), 116-122.

Wena, M. (2009). Strategi Pembelajaran Inovatif Kontemporer. Jakarta: Bumi aksara.

Windarti. (2015). Pengembangan Modul Pembelajaran Logika yang Memuat Pendidikan Karakter untuk Siswa Kelas X SMK. Jurnal Pendidikan Matematika, 10(1), 106-116.

\begin{tabular}{|l|l|l|l|}
\hline Accepted Date & Revised Date & Decided Date & Accepted to Publish \\
\hline 04 September 2020 & 10 September 2020 & 30 Oktober 2020 & Ya \\
\hline
\end{tabular}

